\title{
Clinical features, comorbid mental disorders and treatment outcomes in female patients with alcohol and drug use disorder admitted to an outpatient treatment unit: $A$ retrospective study
}

\author{
Bir ayaktan tedavi birimine başvuran alkol ve madde kullanım bozukluğu tanılı \\ kadın hastalarda klinik özellikler, ek ruhsal hastalıklar ve tedavi sonuçları:
}

Retrospektif bir çalışma

Ebru Aldemir ${ }^{1}$

${ }_{1}^{1}$ M.D., Institute on Drug Abuse, Toxicology and Pharmaceutical Science, Izmir, Turkey, https://orcid.org/0000-0002-3808-1956 SUMMARY

ÖZET

Objective: The studies on alcohol/drug addiction have historically neglected female patients and the results of most studies exclusively conducted on male patients have been generalized to include female population. This study aims to retrospectively investigate the sociodemographic characteristics, alcohol/drug consumption characteristics, comorbid mental illnesses, treatment and follow-up results in female patients who applied to an outpatient addiction clinic for the treatment of alcohol/drug use disorder. Method: The patient files of the consecutive 68 women who visited Ege University Outpatient Addiction Clinic between May 1, 2013 and August 31, 2018 and were diagnosed with alcohol/drug use disorder according to DSM-5 were analyzed. Results: The findings revealed that $60.3 \%$ of patients had alcohol, $39.7 \%$ had drug use disorder. The drug mainly used by the ones diagnosed with drug use disorder was polydrug with a ratio of $44.4 \%$. The duration of problematic alcohol use in the women diagnosed with alcohol use disorder was $8.3 \pm 7.8$ years, the duration of problematic drug use in the women diagnosed with drug use disorder was $7.6 \pm 5.4$ years. The age of onset of problematic alcohol use in the group with alcohol use disorder was higher than the age of onset of problematic drug use in the group with drug use disorder $(t=3.643, p=0.001)$. Depressive disorder was observed in $54.2 \%$ of all patients. $70.5 \%$ of patients attended outpatient clinic follow-up at least for a period of 1 month, $47.9 \%$ of the patients who attended follow-up appointments at least for a period of 1 month received maintenance treatment and $37.5 \%$ of those maintained complete abstinence during that period. Discussion: The findings of this study with the largest sample in our country where sociodemographic and clinical characteristics are evaluated in a group of female patients diagnosed with alcohol/drug use disorder should be developed and supported by controlled and longitudinal follow-up studies.

Key Words: Alcohol use disorder, addiction, gender differences, drug use disorder, women
Amaç: Alkol ve madde bağımlılığına yönelik yapılan çalışmalar, tarihsel olarak, kadın hastaları ihmal etmiş ve sadece erkek hastalarda yapılan çoğu çalışmanın sonuçları kadın popülasyonuna genelleştirilmiştir. Bu çalışmada, alkol/madde kullanım bozukluğu nedeniyle tedavi olmak üzere bir bağımlılık polikliniğine başvuran kadın hastalarda, sosyodemografik özelliklerin, alkol/madde kullanım özelliklerinin, ek ruhsal hastalıkların ve tedavi ve izlem sonuçlarının geriye dönük olarak incelenmesi amaçlanmıştır. Yöntem: Ege Üniversitesi Bağımlılık Polikliniği'ne 1 Mayıs 2013 ile 31 Ağustos 2018 tarihleri arasında ardışık olarak başvuran ve DSM 5'e göre alkol/madde kullanım bozukluğu tanısı alan 68 kadın olgunun dosyası incelendi. Bulgular: Olguların \%60.3'ünde alkol, \%39.7'sinde madde kullanım bozukluğu mevcuttu. Madde kullanım bozukluğu tanısı olanlarda ağırlıklı olarak kullanılan madde \%44.4 ile çoğul madde idi. Alkol kullanım bozukluğu tanılı olgularda sorunlu alkol kullanımı süresi $8.3 \pm 7.8$ yıl, madde kullanım bozukluğu tanılı olgularda sorunlu madde kullanımı süresi $7.6 \pm 5.4$ yıldı. Alkol kullanım bozukluğu olan grubun sorunlu alkol kullanımına başlama yaşı, madde kullanım bozukluğu olan grubun sorunlu madde kullanımına başlama yaşından daha büyüktü $(t=3.643, p=0.001)$. Tüm olguların \%54.2'sinde depresif bozukluk mevcuttu. Olguların \%70.5'i en azından 1 ay süreyle kontrole gelmiş, en azından 1 ay süreyle kontrole gelen olguların \%47.9'u idame tedavi almış ve kontrole geldiği süre boyunca \%37.5'i tam ayıklığı sağlamıştı. Sonuç: Alkol/madde kullanım bozukluğu tanılı kadın hasta grubunda, sosyodemografik ve klinik özelliklerin değerlendirildiği, ülkemizdeki en geniş örneklemli bu çalışmanın bulguları, kontrollü ve uzunlamasına izlemli çalışmalarla geliştirilmeli ve desteklenmelidir.

Anahtar Sözcükler: Alkol kullanım bozukluğu, bağımlııı, cinsiyet farklılıkları, kadınlar, madde kullanım bozukluğu 


\section{INTRODUCTION}

It is known that the ratios of addictive substance use in women are lower than men, and the addictive substance preference of women is also different. In the 2018 World Drug Report, it was reported that males prefer drugs such as cannabis, cocaine and heroin whilst women tend to use more opioid analgesics and sedatives/hypnotics (1). However, recent studies show that the rates of alcohol, cannabis, opioid and cocaine consumption among women have increased much faster than men and that the prevalence of substance use between the genders is approaching each other (2). According to the United States 2015 data, the prevalence of alcohol use disorder in women aged 12 years and over is $4.1 \%$, the prevalence of illegal drug use disorder is $2 \%$ whereas these are $7.8 \%$ and $3.8 \%$ in men, respectively (3).

The convergence between the prevalence rates of alcohol/drug use in female and male individuals was not observed for the prevalence of seeking treatment in both genders. Still, a very small portion of women could be involved in the treatment process due to alcohol/drug use problems. For example, according to the report of the European Monitoring Center for Drugs and Drug Addiction (EMCDDA) of 2018, 16\% of the individuals who started treatment for cannabis use, $27 \%$ of those undergoing treatment for amphetamine use, 20\% of those undergoing treatment for heroin use and $14 \%$ of the individuals undergoing treatment due to cocaine use are women (4).

Acute and long-term effects of the substances, users motive behind alcohol/drug use, the development of the problem and the results show differences in men and women with alcohol/drug use problems $(2,5)$. The factors causing these differences are very important since they have a direct impact on the appropriate clinical treatment of the problem of alcohol/drug use disorders.

When considered from an epidemiological point of view, as can be understood from the above-stated data, a small proportion of women still suffer from alcohol/drug use disorder. When considered with a sociocultural perspective, women with alcohol/drug use disorder problems are stigmatized more compared to men, thus preventing women from seeking help. Furthermore, women may be more vulnerable in all stages of the addiction process in terms of biological (metabolic system, gonadal hormones, dysmorphic brain organization) and social aspects (complex roles such as being a mother, partner, caregiver, unemployment rates) $(2,5,6)$. Studies show that women start using alcohol/drug at a later age, but that the course of problem of alcohol/drug use could be more severe in women in terms of both alcohol/drug consumption and the associated psychopathological symptoms (especially anxiety and mood disorders) $(7,8)$. In addition, women's alcohol/drug use disorder problems have a greater impact on their families, social lives and employment. This may cause the existing clinical aspect to become more complex $(9,10)$.

Recent studies consider gender differences in terms of severity and course of the disease, but also focus on them in terms of treatment motivation, treatment effectiveness and therapeutic outcomes. Some studies have shown that women are better motivated for treatment, participate more in selfhelp activities and reveal to have better treatment results, while some studies have shown that female patients are not different from male patients in terms of compliance and completion of the treatment process $(8,11)$.

Clarification of the above-mentioned differences may contribute to the development of gender-specific treatment strategies which are more effective for women. This study aims to retrospectively investigate the sociodemographic characteristics, alcohol/drug consumption characteristics, comorbid mental illnesses, treatment and follow-up results in female patients who attended to an outpatient addiction clinic for the treatment of alcohol or drug use disorder.

\section{METHOD}

In this study of retrospective design, the female patients who consecutively visited Ege University Outpatient Addiction Clinic between May 2013 and August 2018 were included. Ege University Addiction Outpatient Clinic is a unit where the 
treatment of alcohol/drug use disorders is primarily carried out in outpatient setting and where the decision to be admitted to the inpatient unit is taken when necessary.

The medical records of 68 female patients who consecutively visited the outpatient clinic between May 1, 2013 and August 31, 2018 and who were diagnosed with alcohol or drug use disorder according to DSM-5 (12) were accessed. From the records of these cases, data related to sociodemographic characteristics (age, education, marital and occupational status, living environment), alcohol/drug use characteristics (duration of problematic alcohol/drug use, type of drug used, route of administration, amounts and frequency of alcohol/drug use, history of drug use by intravenous injection and syringe sharing, whether there is abstinence for over a month or not, the longest abstinence period in the cases with abstinence for more than a month, number of treatment visits and history of hospitalization for alcohol/drug use disorder, history of problematic alcohol/drug use by the first, second and third degree relatives), existence of comorbid medical diseases, history of suicide attempts, comorbid mental disorders identified as the result of clinical evaluation conducted according to DSM-5, the applied psychopharmacological treatments and follow-up process have been obtained. With regard to the follow-up process, patients were categorized into five groups as those who did not come to the follow-up appointment, who attended the first month's follow-up, who attended follow-ups in the first 3 months, who attended follow-ups in the first 6 months and those who attended follow-up appointments in the first 12 months. The number of days of alcohol/drug use by the patients during the follow-up period was evaluated based on their self-reports.

Ethical approval for this study was obtained from Ethical Council of Ege University (approval number: 19-12T/43).

\section{Statistical analysis}

The analysis of the data obtained with the defined method was performed with the assistance of the SPSS 21.0 statistical package program. Average and standard deviation were given as the descriptive statistics related to the normally distributed quantitative data and median was given as the descriptive statistics for the quantitative data without normal distribution. Pearson chi-square test or Fisher's exact test was applied to evaluate the difference between the groups in the presence of ca-tegorical data. In the data revealing normal distribution parameters, Student t-test was used for the comparison of two group averages and MannWhitney $U$ test was used for the data without normal distribution. In the study, $\mathrm{p}<0.05$ was chosen as the level of statistical significance.

\section{RESULTS}

\section{Sociodemographic characteristics}

The data of 68 female patients diagnosed with alcohol or drug use disorder were retrospectively screened. The sociodemographic characteristics of the patients showing age, education, marriage, occupational status and living environment are given in Table 1 . Thirty-six $(52.9 \%)$ of all cases stated that they had children.

Table 1. Sociodemographic characteristics

\begin{tabular}{ll}
\hline & Mean-SD or n (\%) \\
\hline Age & $36.7-11.9$ \\
\hline Duration of education (years) & $11.6-3.3$ \\
\hline Marital status & $30(44.1)$ \\
Married & $21(30.9)$ \\
Divorced/Separated & $17(25)$ \\
\hline Occupational status & \\
Unemployed & $31(45.6)$ \\
Employed & $27(39.7)$ \\
Student & $4(5.9)$ \\
Retired & $6(8.8)$ \\
\hline Living environment & $9(13.2)$ \\
Alone & $59(86.8)$ \\
With a relative (spouse, parent, children, etc.) & \\
\hline
\end{tabular}


Table 2. Characteristic of alcohol/drug use

\begin{tabular}{ll}
\hline & Mean-SD or Median or n (\%) \\
\hline Substance that motivated treatment & $41(60.3)$ \\
Alcohol & $27(39.7)$ \\
Drug & 6 \\
\hline Duration of problematic alcohol/drug use (years) & $32(69.6)$ \\
\hline Frequency of alcohol use & $10(21.7)$ \\
Every day & $4(8.7)$ \\
3-4 days a week & $22(81.5)$ \\
1-2 days a week & $4(14.8)$ \\
\hline Frequency of drug use & $1(3.7)$ \\
4 times a week or more often & $8.5-3.8$ \\
2-3 times a week & $2.9-2.7$ \\
2-4 times a month & $4(14.8)$ \\
\hline Amounts of daily use & $23(85.2)$ \\
Alcohol (standart drink/day) & \\
Drug (times/day) & $21(30.9)$ \\
\hline Intravenous administration & $47(69.1)$ \\
Present & 7 \\
Absent & \\
\hline Abstinence longer than one month & \\
Present & \\
Absent &
\end{tabular}

\section{Characteristics of alcohol and drug use}

In 2013, 3 female patients $(4.4 \%)$; in 2014, 15 female patients $(22.1 \%)$; in 2015,12 female patients $(17.6 \%)$; in 2016, 11 female patients $(16.2 \%)$; in 2017, 4 female patients $(5.2 \%)$ and in 2018, 23 (33.8\%) female patients were admitted to the outpatient clinic due to alcohol/drug use problem. Among the 68 patients, $41(60.3 \%)$ had been diagnosed with alcohol use disorder and 27 patients (39.7\%) with drug use disorder. The median duration of problematic alcohol/drug use in all patients, whose alcohol/drug use characteristics are given in Table 2, was 6 years.

Out of the female patients with drug use disorder, 5 of them (18.5\%) used mainly opioid, 4 (14.8\%) used cannabis, $3(11.1 \%)$ were on sedative/hypnotic drugs, 2 (7.4\%) used methamphetamine, 1 (3.7\%) used caffeine and $12(44.4 \%)$ used multiple drugs. Twelve $(17.6 \%)$ of all patients $(n=68)$ had additional substance use at a non-problematic level. Among patients with drug use disorder, 8 (29.6\%) reported smoking as a route of administration, 7 $(25.9 \%)$ reported oral administration, $5(18.5 \%)$ reported use via snorting, $3(11.1 \%)$ reported intravenous administration, and 4 (14.8\%) (individuals with polydrug use) reported several routes of administration (smoking and oral administration, smoking and intravenous administration, smoking and snorting). No syringe sharing was reported in any of the 4 patients with intravenous drug use. Only one patient reported using the same syringe repeatedly.

When the severity of alcohol/drug use disorder was evaluated according to DSM-5, it was observed that 12 of the patients $(17.6 \%)$ suffered from a mild disorder, 23 patients $(33.8 \%)$ suffered from a moderate disorder and that 33 of the patients (48.5\%) suffered from a severe disorder. 1st, 2nd and 3rd degree relatives of the 22 patients $(53.7 \%)$ with alcohol use disorder, 8 patients $(29.6 \%)$ with drug use disorder and of all 30 patients $(44.1 \%)$ had alcohol/drug use disorder problems. The median number of visits for treatment related to alcohol/drug use disorder was 2 . History of hospitalization due to alcohol/drug use disorder was present in 8 of the patients $(11.8 \%)$. Thirteen of all patients $(19.1 \%)$ had comorbid medical diseases.

When the women with alcohol use disorder were compared with the women with drug use disorder, it was observed that the age of the patients with alcohol use disorder $(40.8 \pm 9.4)$ was significantly higher than those with drug use disorder (30.4 \pm 
Clinical features, comorbid mental disorders and treatment outcomes in female patients with alcohol and drug use disorder admitted to an outpatient treatment unit: A retrospective study

Table 3. Comparison of the patients with alcohol and drug use disorders

\begin{tabular}{|c|c|c|c|}
\hline & $\begin{array}{l}\text { Patients with AUD* } \\
\mathrm{n}=41\end{array}$ & $\begin{array}{l}\text { Patients with DUD ** } \\
\mathrm{n}=27\end{array}$ & $\begin{array}{l}\text { Statistical } \\
\text { analysis }\end{array}$ \\
\hline Age (mean-SD) & $40.8-9.4$ & $30.4-12.7$ & $\begin{array}{l}\mathrm{t}=3.646 \\
\mathbf{p}=\mathbf{0 . 0 0 1}\end{array}$ \\
\hline Duration of education (years) (mean-SD) & $12.4-3.1$ & $10.3-3.1$ & $\begin{array}{l}\mathrm{t}=2.619 \\
\mathbf{p}=\mathbf{0 . 0 1 1}\end{array}$ \\
\hline $\begin{array}{l}\text { Marital status [n (\%)] } \\
\text { Married } \\
\text { Single/divorced/separated }\end{array}$ & $\begin{array}{l}14(34.1) \\
27(65.9)\end{array}$ & $\begin{array}{l}7(25.9) \\
20(74.1)\end{array}$ & $\begin{array}{l}\mathrm{x}_{(1)}^{2}=0.515 \\
\mathrm{p}=0.473\end{array}$ \\
\hline $\begin{array}{l}\text { Occupational status [n (\%)] } \\
\text { Unemployed } \\
\text { Employed } \\
\text { Other (student, retired) }\end{array}$ & $\begin{array}{l}16(39) \\
17(41.5) \\
8(19.5) \\
\end{array}$ & $\begin{array}{l}15(55.6) \\
10(37) \\
2(7.4) \\
\end{array}$ & $\begin{array}{l}\mathrm{x}_{(2)}^{2}=2.678 \\
\mathrm{p}=0.262\end{array}$ \\
\hline $\begin{array}{l}\text { Living environment }[\mathrm{n}(\%)] \\
\text { Alone } \\
\text { With a relative } \\
\quad \text { (spouse, parent, children, etc.) }\end{array}$ & $\begin{array}{l}6(14.6) \\
35(85.4)\end{array}$ & $\begin{array}{l}3(11.1) \\
24(88.9)\end{array}$ & $\mathrm{p}=1.000$ \\
\hline $\begin{array}{l}\text { Having children [n (\%)] } \\
\text { Yes } \\
\text { No }\end{array}$ & $\begin{array}{l}28(68.3) \\
13(31.7)\end{array}$ & $\begin{array}{l}8(29.6) \\
19(70.4)\end{array}$ & $\begin{array}{l}\mathrm{x}_{(1)}^{2}=9.768 \\
\mathbf{p}=\mathbf{0 . 0 0 2}\end{array}$ \\
\hline $\begin{array}{l}\text { Duration of problematic alcohol/drug use (years) } \\
\text { (mean-SD) }\end{array}$ & $8.3-7.8$ & $7.6-5.4$ & $\begin{array}{l}\mathrm{t}=0.431 \\
\mathrm{p}=0.668\end{array}$ \\
\hline $\begin{array}{l}\text { Age of onset of problematic alcohol/drug use } \\
\text { (mean-SD) }\end{array}$ & $32.3-9.8$ & $23-10.6$ & $\begin{array}{l}t=3.643 \\
\mathbf{p}=\mathbf{0 . 0 0 1}\end{array}$ \\
\hline $\begin{array}{l}\text { Abstinence longer than one month [n (\%)] } \\
\text { Present } \\
\text { Absent }\end{array}$ & $\begin{array}{l}11(26.8) \\
30(73.2)\end{array}$ & $\begin{array}{l}10(37) \\
17(63)\end{array}$ & $\begin{array}{l}x^{2}(1)=0.795 \\
p=0.373\end{array}$ \\
\hline Duration of abstinence (months) ( $^{* * *}$ (median) & 12 & 5.5 & $\begin{array}{l}\mathrm{u}=39.000 \\
\mathrm{p}=0.258\end{array}$ \\
\hline $\begin{array}{l}\text { History of hospitalization [n (\%)] } \\
\text { Present } \\
\text { Absent }\end{array}$ & $\begin{array}{l}2(4.9) \\
39(95.1)\end{array}$ & $\begin{array}{l}6(22.2) \\
21(77.8)\end{array}$ & $\mathrm{p}=0.051$ \\
\hline $\begin{array}{l}\text { History of suicide attempt [n (\%)] } \\
\text { Present } \\
\text { Absent }\end{array}$ & $\begin{array}{l}7(17.1) \\
34(82.9) \\
\end{array}$ & $\begin{array}{l}5(18.5) \\
22(81.5)\end{array}$ & $\mathrm{p}=1,000$ \\
\hline $\begin{array}{l}\text { Family history of problematic alcohol/drug use [n } \\
(\%)] \\
\text { Present } \\
\text { Absent }\end{array}$ & $\begin{array}{l}22(53.7) \\
19(46.3)\end{array}$ & $\begin{array}{l}8(29.6) \\
19(70.4)\end{array}$ & $\begin{array}{l}x^{2}(1)=3.813 \\
p=0.051\end{array}$ \\
\hline $\begin{array}{l}\text { Comorbid medical disease [n (\%)] } \\
\text { Present } \\
\text { Absent }\end{array}$ & $\begin{array}{l}9(22) \\
32(78) \\
\end{array}$ & $\begin{array}{l}4(14.8) \\
23(85.2)\end{array}$ & $\begin{array}{l}\mathrm{x}^{2}{ }_{(1)}=0.536 \\
\mathrm{p}=0.464\end{array}$ \\
\hline $\begin{array}{l}\text { Comorbid mental disorder [n (\%)] } \\
\text { Present } \\
\text { Absent }\end{array}$ & $\begin{array}{l}27(65.9) \\
14(34.1) \\
\end{array}$ & $\begin{array}{l}21(77.8) \\
6(22.2) \\
\end{array}$ & $\begin{array}{l}\mathrm{x}_{(1)}^{2}=1.115 \\
\mathrm{p}=0.291\end{array}$ \\
\hline $\begin{array}{l}\text { Attending follow-up appointment at least for the first } \\
\text { month } \\
\text { Present } \\
\text { Absent }\end{array}$ & $\begin{array}{l}26(63.4) \\
15(36.6)\end{array}$ & $\begin{array}{l}22(81.5) \\
5(18.5)\end{array}$ & $\begin{array}{l}\mathrm{x}_{(1)}^{2}=2.559 \\
\mathrm{p}=0.110\end{array}$ \\
\hline
\end{tabular}

*AUD: Alcohol use disorder **DUD: Drug use disorder

*** The data of the patients who had abstinence longer than one month were evaluated.

12.7) $(\mathrm{t}=3.646, \mathrm{p}=0.001)$. The duration of education was longer in patients with alcohol use $(12.4 \pm 3.1)$ compared to the patients with drug use $(10.3 \pm 3.1)(t=2.619, \mathrm{p}=0.011)$. No significant differences between the two groups have been observed in terms of marital status (single/divorced/separated vs. married), occupational status and living environment $\left(X^{2}(1)=0.515\right.$, $p=0.473 ; X^{2}(2)=2.678, p=0.262 ; p=1.000$, respectively). While $68.3 \%(n=28)$ of the women in the alcohol group had children, $29.6 \%(n=8)$ of the women in the drug group had children. There was a statistically significant difference between the two groups in terms of having children $\left(X^{2}(1)=9.768\right.$, $\mathrm{p}=0.002$ ). 
Table 4. Outcomes of patients with alcohol/drug use disorder during treatment and follow-up

\begin{tabular}{lc}
\hline \multicolumn{2}{c}{ Table 4. Outcomes of patients with alcohol/drug use disorder during treatment and follow-up } \\
\hline Number of patients who attended follow-up appointments & Median or n (\%) \\
In follow-up month 1 & $19(27.9)$ \\
In follow-up month 3 & $16(23.5)$ \\
In follow-up month 6 & $4(5.9)$ \\
In follow-up month 12 & $9(13.2)$ \\
Didn t attend follow-up appointments & $20(29.4)$ \\
\hline Number of patients who maintained abstinence during follow-up & $5(26.3)^{*}$ \\
In follow-up month 1 & $8(50)^{*}$ \\
In follow-up month 3 & $1(25)^{*}$ \\
In follow-up month 6 & $4(44.4)^{*}$ \\
In follow-up month 12 & \\
Number of days of self -reported alcohol/drug use during follow -up in & 3 \\
cases who could not maintain abstinence & 3.5 \\
In follow-up month 1 & 14 \\
In follow-up month 3 & 4 \\
In follow-up month 6 & \\
In follow-up month 12 &
\end{tabular}

No significant difference was observed between the two groups in terms of duration of problematic alcohol/drug use, abstinence longer than one month and the longest abstinence period $(\mathrm{t}=0.431$, $\mathrm{p}=0.668 ; \quad \mathrm{X}^{2}(1)=0.795, \quad \mathrm{p}=0.373 ; \quad \mathrm{u}=39.000$, $p=0.258$ respectively). The age of onset $(32.3 \pm 9.8)$ of problematic alcohol use in the patients diagnosed with alcohol use disorder was higher than the age of onset of problematic drug use in the patients diagnosed with drug use disorder $(\mathrm{t}=3.643$, $\mathrm{p}=0.001$ ). There was no significant difference between the two groups in terms of history of hospitalization, history of suicide attempt, family history of problematic alcohol/drug use, comorbid medical diseases and comorbid mental disorders $\left(\mathrm{p}=0.051 ; \quad \mathrm{p}=1,000 ; \quad \mathrm{X}^{2}(1)=3.813, \quad \mathrm{p}=0.051 ;\right.$ $X^{2}(1)=0.536, \quad p=0.464 ; \quad X^{2}(1)=1.115, \quad p=0.291$ respectively). There was no significant difference between the two groups in attending the follow-up appointments for at least one month $\left(X^{2}(1)=2.559\right.$, $\mathrm{p}=0.110$ ).

The data of the comparisons in terms of sociodemographic characteristics and disease characteristics of the patients with alcohol and drug use disorders are given in Table 3.

\section{Comorbid mental disorders}

It was seen that $48(70.6 \%)$ of the patients were diagnosed with comorbid mental disorders as the result of the clinical evaluations considering the complaints expressed by the patients during the psychiatric interviews and taking into account DSM-5. Out of these patients with comorbid mental disorders, $26(54.2 \%)$ were diagnosed with depressive disorder, $5(10.4 \%)$ with anxiety disorder, $4(8.3 \%)$ with bipolar disorder, $4(8.3 \%)$ with attention deficit/hyperactivity disorder, $3(6.3 \%)$ with obsessive-compulsive disorder, 3 (6.3\%) with schizophrenia spectrum and other psychotic disorders and $3(6.3 \%)$ with other mental disorders (1 with anorexia nervosa and depressive disorder, 1 with bulimia nervosa, 1 with attention deficit/hyperactivity disorder and depressive disorder). History of suicide attempt was present in 12 of the patients $(17.6 \%)$. Ten $(83.3 \%)$ of the patients with a history of suicide attempt had comorbid mental disorders.

No significant difference was detected between the group with any comorbid mental disorder and the group without in terms of duration of problematic alcohol/drug use $(\mathrm{t}=1.292, \mathrm{p}=0.209)$, abstinence longer than one month $\left(X^{2}(1)=0.010, p=0.919\right)$, the longest abstinence period $(u=39.500$, $\mathrm{p}=0.667)$, number of visits for addiction treatment $(\mathrm{u}=476.500, \mathrm{p}=0.957)$, history of hospitalization due to alcohol/drug use disorder ( $\mathrm{p}=0.100)$, history of suicide attempts $(\mathrm{p}=0.486)$, attending follow-up appointments at least for a month during the follow-up period $\left(\mathrm{X}^{2}(1)=3.316, \mathrm{p}=0.069\right)$ and hospitalization during the follow-up period $(\mathrm{p}=0.100)$. 


\section{Treatment and follow-up}

The treatments recommended to the patients who attended outpatient clinic follow-up at least for 1 month were as follows (after the detox treatment has been applied if required): Eight patients $(16.7 \%)$ received only maintenance treatment, 10 patients $(20.8 \%)$ received the combination of maintenance and antidepressant (AD) treatment, 4 patients $(8.3 \%)$ received the combination of maintenance, $\mathrm{AD}$ and antipsychotic (AP) treatment, 1 patient $(2.1 \%)$ received the combination of maintenance and AP combination treatment, 11 patients $(22.9 \%)$ received only $\mathrm{AD}$ treatment, 1 patient (2.1\%) received only AP treatment, 3 patients $(6.3 \%)$ received the combination of $\mathrm{AD}$ and $\mathrm{AP}$ treatment and 5 patients $(5.4 \%)$ received treatments of other psychotropics (mood stabilizers, stimulants, etc.) and combinations. While 3 patients $(6.3 \%)$ did not accept any treatment, 2 patients $(4.2 \%)$ were deemed to be appropriate for drug-free follow-up. The medications used in the maintenance treatment for alcohol use disorder were naltrexone, nalmefene, acamprosate and disulfiram and the one used for the maintenance treatment of opioid use disorder was buprenorphine/naloxone. Serotonin and serotonin-noradrenaline reuptake inhibitors were preferred as $\mathrm{AD}$ and second generation APs were preferred as AP.

In terms of the follow-up period, it was seen that 20 patients in total $(29.4 \%)$ did not attend the followup appointment after the first admission, 15 of whom $(36.5 \%)$ had alcohol use disorder and 5 of whom $(18.5 \%)$ had drug use disorder. Forty-eight $(70.5 \%)$ of all patients attended for at least one month. During the follow-up period, 8 patients $(11.8 \%)$ were hospitalized. Six $(75 \%)$ of these patients were diagnosed with comorbid mental disorders. The outcomes of treatment and follow-up of all patients have been given in Table 4. Seven $(38.8 \%)$ of the 18 women who maintained abstinence during the follow-up period were receiving maintenance treatment for alcohol/drug use problems. Six of these patients were diagnosed with alcohol use disorder and 1 with drug use disorder. As the maintenance treatment, 5 patients received acamprosate, 1 patient received disulfiram and 1 patient received buprenorphine/naloxone combi- nation. When all patients were evaluated, no significant difference have been identified between the women who received any maintenance treatment $(\mathrm{n}=23,47.9 \%)$ and those who did not $(\mathrm{n}=25$, $52.1 \%$ ) in terms of maintaining abstinence during the follow-up period $\left(X^{2}(1)=0.941, p=0.332\right)$ (the patients who did not attend the follow-up appointment after the first admission have not been included in this analysis).

\section{DISCUSSION}

This study aimed to retrospectively investigate the sociodemographic characteristics, characteristics of alcohol/drug use, comorbid mental disorders and treatment and follow-up results in female patients who attended to an outpatient addiction clinic for the treatment of alcohol or drug use disorder.

In this study, the files of 68 women who consecutively visited Ege University Outpatient Addiction Clinic between May 1, 2013 and August 31, 2018 and who were diagnosed with alcohol or drug use disorder according to DSM-5 were included. As far as we know, this study is the most comprehensive one in our country to evaluate the sociodemographic, clinical and treatment outcomes retrospectively in women applying to addiction outpatient treatment programs. The number of female patients in other studies is quite low and the data of the studies is not sufficient to allow a comparison to be made (13-15).

The findings of this study revealed that $60.3 \%$ of the patients who were included in the evaluation had alcohol use disorder and $39.7 \%$ of the patients had drug use disorder. The prevalence of the drugs mainly used by the ones diagnosed with drug use disorder was $44.4 \%$ for polydrugs, $18.5 \%$ for opioids, $14.8 \%$ for cannabis, $11.1 \%$, for sedative/hypnotics, $7.4 \%$ for methamphetamine and $3.7 \%$ for caffeine. The average age for admission to treatment in the women diagnosed with alcohol use disorder was $40.8 \pm 9.4$ and the average age for admission to treatment in the women diagnosed with drug use disorder was $30.4 \pm 12.7$. The current international studies show that the prevalence of alcohol/drug use disorder is increasing among women, whereas the age of admission to treatment 
is decreasing also the ratio of admission to treatment (male:female) dropped from 5:1 to 3:1 (1618). It is expressed that this situation is associated with the changes in cultural and social norms and facilitating women's access to the substances (16). Recent studies again show that female patients still prefer to use prescription drugs, however their use of substances such as alcohol, cannabis, opioid and cocaine is increasing rapidly $(16,19)$.

In this study, it is observed that the duration of problematic alcohol use in the patients diagnosed with alcohol use disorder was $8.3 \pm 7.8$ years, the average age of onset of problematic alcohol use was $40.8 \pm 9.4$ and the duration of problematic drug use in the patients diagnosed with drug use disorder was 7.6 \pm 5.4 years, the age of onset of problematic drug use was $23 \pm 10.6$. It is known that women start using alcohol/drugs at later ages compared to men (20). Many studies reveal that alcohol/drug use disorder in women progresses faster compared to alcohol/drug use disorder in men and women seek for treatment in a much shorter time compared to men (16). This is called the "telescopic" course of the disease. The "telescopic" course has been shown in the use of cannabis, cocaine and opioid but not in heroin use and contradictory results have been observed in alcohol use (20). These contradictory results may arise due to the differences in the study samples. When the samples were examined in detail, it can be observed that the telescopic effect could be detected mostly in severely progressed cases who underwent the treatment process but could not be detected in communitybased studies representing a broader range of severity of disorder. In other words, it can be expressed that a subgroup of women is vulnerable to a faster progression of the disease.

When the female patients with alcohol use disorder and the female patients with drug use disorder were compared in the study, it was observed that the average age and the age of onset of problematic alcohol use in the group with alcohol use disorder was higher than the average age and the age of onset of problematic drug use in the group with drug use disorder. Similar results have been observed in national and international studies as for the patients who applied for outpatient treatment, but where the number of male patients pre- vailed $(13,15,21)$. This situation is thought to be associated with the relatively higher social acceptance of alcohol and its detrimental effects arising at a later age.

In this study, comorbid mental disorders were detected in $70.6 \%$ of the female patients. Depressive disorder was observed in $54.2 \%$ of the patients, anxiety disorder in $10.4 \%$, bipolar disorder in $8.3 \%$, attention deficit/hyperactivity disorder in $8.3 \%$, obsessive-compulsive disorder in $6.3 \%$ and schizophrenia spectrum and other psychotic disorders were observed in $6.3 \%$. Furthermore, $19.1 \%$ of the patients had comorbid medical diseases. Women who apply for treatment due to alcohol/drug use disorder suffer more deterioration in terms of occupational, social, family, medical and psychiatric functionality compared to men $(16,22,23)$. There are also differences related to gender in terms of comorbid mental disorders. While depressive and anxiety disorders are more common in women, antisocial personality and conduct disorders are observed more commonly in men $(24,25)$. Comorbid mental disorders adversely affect the treatment process of alcohol/drug use disorders, especially in terms of seeking treatment and post-treatment outcomes (26). Therefore, comorbid mental disorders may be an important treatment target in female patients.

When the study findings were evaluated in terms of treatment, $16.7 \%$ of the patients who had regular visits for at least 1 month received only maintenance treatment, $20.8 \%$ received combined maintenance and $\mathrm{AD}$ treatment, $8.3 \%$ received combined maintenance, $\mathrm{AD}$ and $\mathrm{AP}$ treatment, $2.1 \%$ received combined maintenance and AP treatment, $22.9 \%$ received only $\mathrm{AD}$ treatment; $2.1 \%$ received only AP treatment, 6.3\% received combined $\mathrm{AD}$ and $\mathrm{AP}$ treatment and $5.4 \%$ received other psychotropic (mood stabilizer, stimulant, etc.) treatments. Furthermore, $70.5 \%$ of all patients attended their follow-up appointment at least for a period of 1 month and $37.5 \%$ of those who attended follow-up reviews maintained abstinence during that period. Currently, even if a right diagnosis is made, only $38 \%$ of the current programs can meet the treatment requirements of women (27). Factors such as trauma exposure, comorbid mental disorders, having children, rela- 
tionships with partners/spouses and physical health may affect the treatment outcomes in women (20). In addition, male patient-oriented diagnosis process and treatment models, insufficiency in the education of health-care workers regarding the individual needs of women, lack of comprehensive services in a single unit, lack of prenatal and postnatal care services for pregnant women, feeling of shame and guilt due to the internalization of social stigma, fear of leaving/losing children and lack of information related to possible services are the most important barriers precluding women to receive treatment for alcohol/drug use problems. For this reason, as supported by randomized controlled trials, treatment programs prepared for women should provide comprehensive services for multiple problems, and should be holistic by addressing the physical, emotional and mental aspects of women's recovery including the assisted services such as housing and childcare (28-30). In addition, the fact that the problem of education and unemployment is not overlooked and the setting of educational and occupational goals allow women to feel competent, increase their sense of independence and security thus enable them to take more responsibility for their own lives.

This study has several limitations. Firstly, the retrospective design would be a limitation to generalize the results to all women with alcohol/drug use disorder in the society as this study was conducted on women who applied to a specialized treatment unit. Secondly, the differences between the genders could not be determined unique to this study since a male comparison group was absent. Lastly, the data regarding the alcohol/drug use both at the time of the diagnosis and during the follow-up period was determined by the self-reports of the patients which might be subjected to various biases.

Despite its limitations, this study has the largest sample in our country carried out in a group of female patients admitted to a specialized treatment unit with diagnosis of alcohol/drug use disorder. Its descriptive nature provided important data that could light the way to future studies. The findings of this study should be considered as preliminary findings and should be developed and supported by more comprehensive, controlled and longitudinal studies.

Correspondence address: M. D. Ebru Aldemir, Institute on Drug Abuse, Toxicology and Pharmaceutical Science, Izmir, Turkey ozturk.ebru2000@gmail.com

\section{REFERENCES}

1. UNODC. World Drug Report: Women and drugs: Drug use, drug supply and their consequences. [Internet]. United Nations Office on Drugs and Crime. 2018. Available from: https: //www.unodc.org/wdr2018/prelaunch/WDR18_Booklet_5_WO MEN.pdf. Date of access: September 10, 2019.

2. Altintoprak AE. Kadın, Gebelik ve Alkol Madde Kullanım Bozuklukları, in Alkol ve Madde Kullanım Bozuklukları Temel Başvuru Kitabı. Edited by Evren C. Ankara, Türkiye Psikiyatri Derneği Yayınları, 2019, pp. 518-533.

3. Substance Abuse and Mental Health Services Administration. Facing Addiction in America: The Surgeon General's Report on Alcohol, Drugs, and Health. Washington (DC): US Department of Health and Human Services; 2016.

4. Avrupa Uyuşturucu ve Uyuşturucu Bağımlılı̆̆ını İzleme Merkezi. Avrupa Uyuşturucu Raporu 2018: Eğilimler ve Gelişmeler [Internet]. 2018. Available from: http://www.emcdda.europa.eu/system/files/publications/8585/20181816_TDAT18 001TRN_PDF.pdf. Date of access: September 10, 2019.

5. Fernandez-Montalvo J, Lopez-Goñi JJ, Azanza P, Cacho R. Gender differences in drug-addicted patients in a clinical treatment center of Spain. Am J Addict 2014; 23:399-406.

6. DeVito EE, Babuscio TA, Nich C, Ball SA, Carroll KM.
Gender differences in clinical outcomes for cocaine dependence: Randomized clinical trials of behavioral therapy and disulfiram. Drug Alcohol Depend 2014;145:156-167.

7. Green CA. Gender and use of substance abuse treatment services. Alcohol Res Health 2006; 29:55-62.

8. Grella CE, Scott CK, Foss MA. Gender differences in longterm drug treatment outcomes in Chicago PETS. J Subst Abuse Treat $2005 ; 28: 3-12$.

9. Walitzer KS, Dearing RL. Gender differences in alcohol and substance use relapse. Clin Psychol Rev 2006; 26:126-148.

10. Storbjörk J. Gender differences in substance use, problems, social situation and treatment experiences among clients entering addiction treatment in Stockholm. Nordic Studies on Alcohol and Drugs 2011; 28:185-209.

11. López-goñi JJ, Fernández- Montalvo J, Illescas C, Landa N, Lorea I. Determining socio-demographic predictors of treatment dropout: Results in a therapeutic community. Int $\mathbf{J}$ Soc Welf 2008; 17:374-378.

12. Amerikan Psikiyatri Birliği, Ruhsal Bozuklukların Tanısal ve Sayımsal Elkitabı, Beşinci Baskı (DSM-5), Tanı Ölçütleri Başvuru Elkitabı. Köroğlu E (Çeviri Ed.), Hekimler Yayın 
Birliği, Ankara, 2013.

13. Bulut M, Savaş HA, Cansel N, Selek S, Kap Ö, Yumru M, Virit O. Gaziantep Üniversitesi Alkol ve Madde Kullanim Bozuklukları Birimine başvuran hastaların sosyodemografik özellikleri. Bağımlılık Derg 2006;7:65-70.

14. Doğanavşargil ÖG, Önen Sertöz Ö, Coşkunol H, Şen G. EÜTF Psikiyatri Anabilim Dalı Bağımlılık Tedavi Biriminin hasta verilerinin on yıllık geriye dönük olarak incelemesi: Madde kullanan hastaların sosyodemografik özellikleri. Bağımlılık Derg 2004; 5:115-120.

15. Asan Ö, Tıkır B, Okay İhsan T, Göka E. Sociodemographic and clinical features of patients with alcohol and substance use disorders in a specialized unit. Bağımlılık Derg 2015;16:1-8.

16. Hernandez-Avila CA, Rounsaville BJ, Kranzler HR. Opioid, cannabis- and alcohol-dependent women show more rapid progression to substance abuse treatment. Drug Alcohol Depend 2004; 74:265-272.

17. Steingrímsson S, Carlsen HK, Sigfússon S, Magnússon A. The changing gender gap in substance use disorder: A total population-based study of psychiatric in-patients. Addiction 2012; 107:1957-1962.

18. Bilici R, Ünübol B, Çinka E. Kadın, Gebelik ve Bağımlılık, in Bağımlılık Tanı, Tedavi, Önleme. Edited by Öztürk M, Ögel K, Evren C, Bilici R. İstanbul, Yeşilay Yayınları, 2019, pp.557574.

19. Lynch WJ, Roth ME, Carroll ME. Biological basis of sex differences in drug abuse: Preclinical and clinical studies. Psychopharmacology 2002;164:121-137.

20. McHugh RK, Votaw VR, Sugarman DE, Greenfield SF. Sex and gender differences in substance use disorders. Clin Psychol Rev 2018; 66: 12-23.

21. Weisner C. A Comparison of alcohol and drug treatment clients: Are they from the same population? Am J Drug Alcohol Abuse 1992;18:429-444.

22. Sherman BJ, McRae-Clark AL, Baker NL, Sonne SC, Killeen TK, Cloud K, Gray KM. Gender differences among treatment-seeking adults with cannabis use disorder: Clinical profiles of women and men enrolled in the achieving cannabis cessation-evaluating $\mathrm{N}$-acetylcysteine treatment (ACCENT) study. Am J Addict 2017; 26:136-144.

23. McHugh RK, DeVito EE, Dodd D, Carroll KM, Potter JS, Greenfield SF, Connery HS, Weiss RD. Gender differences in a clinical trial for prescription opioid dependence. J Subst Abuse Treat 2013; 45:38-43.

24. Conway KP, Compton W, Stinson FS, Grant BF. Lifetime comorbidity of DSM-IV mood and anxiety disorders and specific drug use disorders: Results from the National Epidemiologic Survey on Alcohol and Related Conditions. J Clin Psychiatry 2006; 67:247-257.

25. Khan S, Okuda M, Hasin DS, Secades-Villa R, Keyes K, Lin $\mathrm{KH}$, Grant B, Blanco C. Gender differences in lifetime alcohol dependence: Results from the national epidemiologic survey on alcohol and related conditions. Alcohol Clin Exp Res 2013; 37:1696-1705.

26. Greenfield SF, Grella CE. What is "women-focused" treatment for substance use disorders? Psychiatr Serv 2009; 60:880-
882.

27. Pape PA, Sarabia SE. Assessment and Treatment of Women with Substance Use Disorders, in Clinical Work with SubstanceAbusing Clients. Edited by Straussner SLA. New York, The Guilford Press, 2014, pp. 442-465.

28. Slesnick N, Zhang J. Family systems therapy for substanceusing mothers and their 8- to 16-year-old children. Psychol Addict Behav 2016; 30:619-629.

29. Slesnick N, Erdem G. Efficacy of ecologically-based treatment with substance-abusing homeless mothers: Substance use and housing outcomes. J Subst Abuse Treat 2013;45:416-425.

30. Hien DA, Wells EA, Jiang H, Suarez-Morales L, Campbell AN, Cohen LR, Miele GM, Killeen T, Brigham GS, Zhang Y, Hansen C, Hodgkins C, Hatch-Maillette M, Brown C, Kulaga A, Kristman-Valente A, Chu M, Sage R, Robinson JA, Liu D, Nunes EV. Multisite randomized trial of behavioral interventions for women with co-occurring PTSD and substance use disorders. J Consult Clin Psychol 2009;77:607-619. 